\title{
Application of Bryophytes and Glass Pumice in Sponge City Landscape Design of Jinan
}

\author{
Danning Han* and Yongsheng Zhao \\ Liaocheng University, Hunan Road, Liaochen, China \\ ${ }^{*}$ Corresponding author
}

\begin{abstract}
Based on analyzing the climatic conditions of Jinan, the physiological characteristics of bryophytes and the features ofglass pumice, this article proved the feasibility of using bryophytes and glass pumice in the ecological landscape construction of this area, and put forward the design methods of using bryophytes and glass pumice in landscaping.
\end{abstract}

Keywords-bryophytes; glass pumice; LID landscape design

\section{INTRODUCTION}

Sponge city, refers to through strengthening the urban planning management, give full play to the rainwater absorbing, storing and slow releasing ability of buildings, roads, green space, water systems and other ecosystems, controlling the rainwater runoff, to reach a naturally urban development mode. Chinese government pays more attentions to sponge city concept in recent years, and put forward a series of related policy measures. Nowadays Chinese ecological system degraded seriously, the contradiction between human actives and the environment has become increasingly prominent. Therefore, there is a strong need of constructing more sponge city to help restore the urban ecological environment. At present, building ecological parks and repairing urban wetlands was the mainly way to help improve the sponge city system, so low impact developed ecological landscape design becomes more important. And how to ensure this kind of landscape design to keep both ecological effect and availability, is a new research direction which is worthy to study.

\section{The NeCEssity of ECOlOgiCAL LANDSCAPE DESIGN IN JINAN SPONGE CITY CONSTRUCTION}

Jinan is one of the first pilot cities for sponge city construction in China. Jinan is temperate monsoon climate, the rainfall distribution is uneven in different seasons and regions of the city. In recent years, the annual precipitation in Jinan was decreased, and affected by global warming, the annual average temperature showed a gradual upward trend. In order to cope with the adverse effects of these climate changes on the urban residential environment, LID ecological landscape design is necessary in Jinan sponge city construction. The climate in Jinan is very representative in the middle of Shandong Province, due to the familiar climate conditions, the LID landscape design method adopted in Jinan can also be a good reference for the sponge city construction of other middle cities in Shandong.

\section{The FEASIBILITy ANALYSIS OF BRyOPHYTES AND GLASS PUMICE USED IN ECOLOGICAL LANDSCAPE DESIGN OF JINAN}

\section{A. Characteristics of Bryophytes}

Bryophyte is a kind of small green plant with simple physiological structure. It often grows into ground cover in natural environment. The stem and leaf of bryophyte can grow into irregular branches and form many small holes, this made bryophyte has a strong ability of water holding.

The biological crusts formed by bryophytes and their soil matrixes can reduce wind erosion and water erosion, reduce soil nutrient loss, and slow down rainfall subsidence, play a role in water storage, soil conservation and soil fertility.

Bryophytes have strong environmental adaptability. They can adapt themselves to different circumstances. And the way bryophytes get nutrients needed for growth is relatively simple. They get nutrients not only from soil or precipitation, but also from atmosphere, tree crown eluviation, rock surfaces eluviation or ground litter eluviation. Some bryophytes also have strong drought tolerance[1].

There are 15 families, 33 genera and 62 species of bryophytes in Jinan[2]. Some of these bryophytes such as Fissidens Bryoides, Dicranodontium, Bryum Argenteum, can be used for urban landscaping. These kinds of bryophytes are more adaptable to the climate of Jinan than the common lawn grass. They have strong capability of propagation and are easy for maintenance[3]. Comparing with traditional lawn grass, using bryophytes in landscape design can also get a good visual effect. Therefore, it is very feasible to use bryophytes instead of common lawn grass in the ecological landscape design in Jinan.

\section{B. Characteristics of Glass Pumice}

Glass pumice is made from waste glass. As a kind of environmental friendly water-storage material, glass pumice can be used for gardening, or used as soil amendment, it can also be used as a ground substance of bryophtes. There are many types and colors of glass pumice to choose from.

\section{SUgGest FOR APPLICATION OF BRYOPHYTES AND GLASS PUMICE IN ECOLOGICAL LANDSCAPE DESIGN}

Due to the actual situation of Jinan, the urban landscape design can be considered from these following aspects.

\section{A. Urban Green Belt Landscape Design}

Bryophytes can be used as lawn to cover ground that under large trees in urban green belts. They can also be used with glass 
pumice to design dry stream or grassed swales. Glass pumice can be mixed with soil and gravel, then be used as bryophytes substance. This method can completely cover the exposed ground surface and effectively reduce the ground surface dust[4]. Bryophytes can absorb nutrients from the natural environment, thereby greatly reducing the labor conservation cost.

\section{B. Industrial Estate landscape Transformation}

Bryophytes are tolerant to heavy metals. They show different morphological characteristics under different concentrations of heavy metals pollutants. Therefore, bryophytes can be used as a kind of environmental pollution monitoring plant. At the same time bryophytes can also adsorb the pollutants to clean the environment that they growth. Due to the construction of the eastern CBD New District, Jinan steelworks, Jinan oil refiner will soon be moved to other place. After the relocation, the old industrial estate will be planned as residential and business district. Bryophytes, such as sphagnum, and glass pumice, can be used in landscape design of this area. They can create a simple and comfortable urban landscape by means of contemporary landscape design, such as adopting geometric segmentation design styles.

\section{Square Landscape Design}

Bryophytes and glass pumice can be used in the square landscape design. The use of bryophytes to decorate small sculptures can emphasize the function of sculpture.

Bryophytes can be planted on the walls and other suitable vertical plane[5]. So that bryophytes can be planted as the pattern designed, to give a kind of landscape visual effects which is similar to the plant relief.

The bryophytes can also be used in flower beds as the embellishment plant in the square landscape, instead of the ornamental flowers. Glass pumice can be used as substance on the surface layer of the flower bed for planting bryophytes. Bryophytes and glass pumice can also be designed as landscape belt on the square. This method can increase the water storage rate of the substance in the flower bed, reduce the artificial irrigation and the dust, and make the flower bed clean.

\section{Bryophytes Park Landscape Design}

Bryophytes can be used as ground cover in the park, and can be grown on the large size ornamental trees to create a peaceful and secluded landscape effect that makes visitors feel like they are in the forest

Bryophytes can be designed to cover the stone or wood bridge over the waterscape in the park, to create a quiet visual beauty. Glass pumice used as substrate can also be used as natural water shore to enrich the landscape gradations.

Bryophytes and glass pumice can be used with stone step or other material, to be designed as path. For example, the trails in the park can be outlined with bryophytes and filled with stone plates, or spliced with different materials to form a different color or different texture of the steps.

\section{CONCLUSION}

Through the above analysis, it can be seen that ecological landscape design is very necessary to the sponge city construction of Jinan. Bryophytes have a strong ability to adapt different environment. Glass pumice can be used as the growth substance of bryophytes. The characteristics of bryophytes and glass pumice enable them to be applied to the ecological landscape design of Jinan. They can be used in the design of urban green belt, industrial estate landscape, square and bryophytes park. Therefore, bryophytes and glass pumice have a good application prospect in the landscape design of Jinan. The application will provide an important reference for the ecological landscape design of other middle cities in Shandong Province

\section{ACKNOWLEDGMENT}

Thanks for the subsidization of Shandong graduate students education creative plan\&project and Shandong higher education scientific plan\&project.

\section{REFERENCES}

[1] Smith A J E., Bryophyte Ecology, London, 1982.

[2] Zuntian.Zhao, Tong Cao, Flora Bryophytorum Shandong Sinicorum, Shandong, 2000.

[3] Xuezhan Lung, Lintao Cao, Kunlun Zhou, Study on bryophyte:growth habit and its applicability in ecological slope protection, Environmental Science \& Technology, 38 (2015) 117-122.

[4] Chen Junhe, Jiang Ming, Zhang Li, Application of Bryophytes in Landscaping, Guangdong Landscape, 32 (2015) 31-34.

[5] Xiaobo He, Lihong Yu, Qixian Lai, Jun Chen, Baolong He, Analysis of Construction of Bryophytes landscape, Journal of Green Science and Technology, 6 (2012), 69-71. 